\title{
Strategic Direction and Sustainable Development in Franchising Organizations: A Conceptual Study
}

\author{
Fauziah Samsudin ${ }^{1}$, Sazali A. Wahab ${ }^{2}$, Ahmad S. A. Latiff ${ }^{2}$, Suzana I. W. Osman ${ }^{3}$, Nur F. M. Zawawi ${ }^{1} \&$ Syed $^{1}$ \\ A. Fazal ${ }^{1,4}$ \\ ${ }^{1}$ Faculty of Entrepreneurship and Business, Universiti Malaysia Kelantan, Kota Bharu, Kelantan, Malaysia \\ ${ }^{2}$ Putra Business School, 43400 UPM Serdang, Selangor Darul Ehsan, Malaysia. \\ ${ }^{3}$ Faculty of Administrative Science and Policy Studies, Universiti Teknologi MARA, Shah Alam, Malaysia \\ ${ }^{4}$ Novel Global Community Educational Foundation (NGCEF), Australia \\ Correspondence: Fauziah Samsudin, Faculty of Entrepreneurship and Business, Universiti Malaysia Kelantan, \\ Kota Bharu, Kelantan, Malaysia. E-mail: fauziah.p14e011p@siswa.umk.edu.my
}

Received: April 19, $2018 \quad$ Accepted: May 11, $2018 \quad$ Online Published: July 29, 2018

doi:10.5539/jsd.v11n4p89 URL: https://doi.org/10.5539/jsd.v11n4p89

\begin{abstract}
Franchising is viewed as a significant industry in contributing to the global economic development by generating an average of $\$ 3.7$ billion in annual franchise sales from 40 countries and provides over 18 million jobs opportunities. Due to the expansion of franchise business markets in Malaysia, the number of franchise outlets keeps increasing more than doubled within six years, with total 10720 outlets in 2010 to 23140 outlets in 2016. To intensify the continuance of this expanding process, franchise entrepreneurs need to conserve a sustainable creative value in undergoing the challenging of the business environment. The limitations of internal and external factors such as core capability, government support and other related dimensions affect the stability of franchise organization. This paper pursues to explore the related existing literature and underpinning theories that reinforce the sustainable development of franchise business. Most of the franchise models are captured in the different analysis of dimensions and strategies on sustainable development goals. The objective of this study is to conceptualize the strategic direction practices and propose a theoretical framework of sustainable franchising that can help the continuance of franchise business. Therefore, by supporting and participation of stakeholders, entrepreneurs, academicians, researchers, and governments, future analysis can develop and expose a sustainable model of franchising.
\end{abstract}

Keywords: franchising, economic development, business environment, sustainable development, Malaysia

\section{Introduction}

Globally, current business trend applied the concept of sustainable strategy plan towards economic growth. Brundtland (WCED) definition indicates, sustainability must seek a way to balance obligations to the present and the future. The World Business Council on Sustainability Development (WBCSD) has presented the result of vision 2050 where the attributes of successful business strategy through understand their current situation and identify the obstacles then create the way to overcome those obstacles (WBCSD, 2015). In order to address sustainability challenges, we need to understand the bottlenecks and take action in line with these barriers. Significance finding by (Blowfield, 2013; Elliot, 2013), sustainability in business is also linked to ethical concerns, involving a commitment to justice between generations in matters of distribution of wealth, working conditions and human rights.

Franchising had benefitted the world economies through its business system. As an accepted business model for economic growth, franchising plays and targeted in local and international market to expose their brand name of goods and services. Cox and Mason (2007) and Kaufmann and Eroglu (1999) analysed the attributes of business format franchising, the significance of sustainability to the system, and the sustainability modification strain of the franchise system. Franchising also contributing to the global economic development by generating an average of $\$ 3.7$ billion in annual franchise sales from 40 countries and provides over 18 million jobs opportunities in both developed and developing markets. Olotu and Awoseila (2011) defined franchising as an agreement between organizations where a producer of product or service grant rights to independent business 
entrepreneur to conduct business in a specific way, designated place and at a certain period of time. Franchising has become a popular strategy for sustainable development in different areas. Chinyoka (2008) said franchising as an alternative strategy for developing enterprises. The purpose of this study is to examine the strategic direction practices towards sustainable development in franchising. This research gathered information from related underpinning theories whether franchising contributes to the business growth. Sivakumar and Schoormans (2011) highlight that franchising as one of the instruments that provides opportunities for employment creation.

The beginning of franchise history of entrepreneurship was in USA like Singer, Kroc, Ford and McCormick (Dicke, 1992) and amazingly generates approximately $\$ 1$ trillion in annual sales (Trutko, Trutko \& Kostecka, 1993). As a successful country in managing franchise industry, USA statistic shows that there was an adding of $\$ 29$ billion in GDP to the USA economy where the gross domestic product (GDP) of the franchise sector is projected to rise 5.6 percent to $\$ 552$ billion in 2016 . The franchise sector will contribute approximately 3 percent of USA GDP in nominal dollars. For the past five years, the average annual job growth in the franchise sector was 2.6 percent nearly 2 percent higher than all business (Economy Outlook, 2016). According to Franchise Times data 2016, 38 percent of the units of the 200 largest USA -based franchisors are already outside the United States. Through emerging economies in retailing, franchising shows an annual growth by 10 percent for the last five years.

In Malaysia, in year 2016, there are about 23140 franchise outlets represent the number of franchisors and franchisees keep increasing since year 2000. It is seen as franchising adopts to expand business trade to global markets. Supported by Olotu and Awoseila (2011) carried out a study that examined the importance of franchising in developing economies. Besides, franchising is a type of businesses that are simple and cheap compare to other type of business. Franchise companies need to develop their system to promote sustainability to avoid any negative factors influence the company potential or reputation. Barnes (2012) had analysed franchising as a strong economic growth and extremely expansion which resulted more entrepreneurs turning to franchise system in a way to rising customer demand. Franchise organization and its environment should support sustainability practices to avoid losses in their business.

In line with the 2030 sustainable development (SD) agenda, franchise business also looking forward with many plans to achieve SD in its industry which globally expanding since 1992. Present situation shows that franchise business is recognized as one of the platform in supporting the 2030's agenda of sustainable economic growth plan through its strategic direction practices. In previous studies, franchising helps on job creation which benefits to the economic value. The franchise entrepreneurs also realized that sustainability aspires to sort out connections and priorities of global responsibilities through focusing on their brands, and identifying what factors stand to avoid lose. This study also, to address the lacking factors that influence the franchise entrepreneurs to participate and contribute in minimizing the failure percentage in franchise business growth.

This study is organized into four sections. Firstly, sustainable in franchise business is defined. Secondly, proposed new franchise model in terms of business growth and sustain through internal and external factors. Thirdly, incorporates the impacts of strategic direction practices based on related factors such as capability of franchise entrepreneurs, government support for business growth, the franchise organization management itself and the consideration of business management through competitive advantage with current situation. Fourthly and last, the effectively managed profitability towards achieving sustainability in franchise business beyond the maturity level in the industry.

This research is aim to gain a deeper understanding of how internal and external factors impact the sustainability of franchise business besides to develop a successful model of sustainable development .Consequently, this paper has two main objectives. Firstly, it discusses specific capabilities of the international and local franchise brands identified in franchising research and ties them to the administrative efficiency in franchise organization. Then to integrate these capabilities into a proposed framework of international and local franchisors types based on the dynamic capabilities perspective of resource-based theory for the effectively managed profitability towards achieving sustainability in franchise business beyond the maturity level in the industry. Secondly, to discuss the influences of government support in this industry and how it can influence the sustainable development of franchises organization. Besides, to find out the opportunities and overcome the challenges for franchise business to live long under strategic direction practices in the organization itself.

\section{Literature Review}

\subsection{Franchise Business Instability - Challenges and Barriers}

Even though, franchise business has been considered as a model of economic growth, the statistic had shown a failure rate especially towards financial stability which is noted as a major challenging issue to them to survive 
in local and international markets.From the statistic and previous studies of both local and international franchise failure rates, it may prove that a lower failure rate can be achieved by a good controlled of franchisor and franchisee on their product brand name in the market, have a sufficient of financial capital, capability in organization management, government support, creditably experienced and skilled, adequately in accommodate with the cultural, economic and political of the market environment.

Using as a reference between a developed and developing country; table 1 shows that the total numbers of franchise business are tremendous differences within Malaysia and USA. The increasing of franchise business volumes to 23,140 in 2016, indicated that franchise industry in Malaysia has a high potential trade and inadequacy a strategic sustainable plan for future business challenges as the failure rate of sustainability is quite high compare to USA's which only 5 percent. From this data, Malaysia could exertion USA as a reference or sample to achieve success in franchise business.

Table 1. Franchise industry statistic in Malaysia vs USA - source MDTM 2010-2016

\begin{tabular}{lll}
\hline Description & $\begin{array}{l}\text { Malaysia 2016 } \\
\text { (Developing country) }\end{array}$ & $\begin{array}{l}\text { USA 2016 } \\
\text { (Developed Country) }\end{array}$ \\
\hline Sales (USD Billion) & 3.4 & 845 \\
GDP (USD Billion) & 1,110 & 14,526 \\
Employment & $1.30 \%$ & $3.5 \%$ \\
Franchise Outlets & 23,140 & 795,932 \\
Failure Rate of sustainability & $20 \%$ & $5 \%$ \\
& (UTM case study 2017) & (USA Business Commerce) \\
\hline
\end{tabular}

Comparing with other countries' business trend, the United States has an entrepreneurial culture element where successful entrepreneurs encourage others to succeed. They have a financial system reinforcement whereby successful entrepreneurs have been supported by investors beyond the initial phase and during to start newly business. There are over 7,000 small local banks from private sectors are ready to provide financial support to new business comers for commercial purposes. However, the government sector does not dare to do the same on the tax systems that promote hard work and long working hours.

An increasing population in United State results to have more youthful workforce which is easier to train and more flexible. They earned more than an hour and work for a longer period of 1,800 per year. In the United States, work is more important than life. Less than 7 percent of the private sector workforce has trade unions and labour laws in the United States are less excruciating than other countries. The USA universities practice entrepreneurship and academic culture for their students and this attract foreign student interest to study there. The 38 percent US GDP is used as expenses of their country compare to Malaysia only $21.2 \%$. A lower percentage means less involvement by government in reducing stimulus works. A positive impact in business due to less regulation results a business- friendly environment. Malaysia also implementing some of the action practices in USA and keeps learning the pro and con of the risks before take it as an example for business failure. A further enhances collaboration between academicians; stakeholder, researchers and entrepreneurs will makes sustainable development in franchise business in future.Further study shows that, an accelerated developing franchise entrepreneurs with insufficient capital, imperil selection of non capability recruitment will put franchise business into major problems in the short and medium terms. According to researchers (Dada et al, 2012; Ketchen et al 2011), 'Despite the fact that franchising keeps on being a critical plan of action globally, the issue of adaption theories in franchising has been predominant open deliberation among both academics and specialists'. Moreover, franchises fail for a few reasons some of which include not enough working capital, lack of franchisor support, personal characteristics, underestimating the amount of work required, badly managing staff, lack of commitment and unrealistic expectations (Nyembe, 2015, July 9; Rose, 2011, September 19). Supporting by Miles (2013) the number of franchise business failures is a problem because of the impact failing businesses has on the economy through employment and unemployment rates.

Typically, franchise entrepreneurs too much depending on the franchisor for them to start off well but cannot last long as the franchise system is there. Franchise entrepreneurs should have self-confidence and capable to run the business by their own in order to sustain. Franchisor is only as their supporter or consultant for certain cases. By 
implementing a positive steps and immediate respond on the challenges, they actually can go further in this industry. (Shukri, 2015) also emphasized research and development (R \& D), value added products and a good system is key to the success of the franchise business today. Before expanding to international markets, Franchise firms should evaluate the population (size of market), consumer ability to purchase, regulatory framework of the government to business and the ability of the currency and the legal system of the country. The main problem with adopting sustainability practices is the lack of required capabilities for sustainability management (Kudla et al., 2012). Thus, the organization requires effective strategies to overcome any limitations in order to be sustainable in the industry. However, these limitations can be overcome if the buyer (franchisee) and supplier firms (franchisor) share one another capabilities and work in close proximity (Ronchi, Luzzini \& Spina, 2007). Despite, the expanding of franchising in local and international business markets, a few studies has been done in Malaysia to address issues such as financial problem for franchise entrepreneurs to survive. This failure phenomenon covers franchisors and franchisees who actually recorded the highest business fall of 5 percent compared to other countries with a maximum of 2.5 percent (Utusan Malaysia, 2003).

The franchise sector in Malaysia saw entrepreneurial involvement declined by 30 percent covering the number of franchisees and franchisors under the Business Transformation Program (BIT). Perbadanan Nasional Bhd. (PNS) owned by the Minister of Finance (Incorporated) being mandated to spearhead the development of the franchise industry in Malaysia is targeting a total of 200 franchise entrepreneurs in 2016, however only about 100 registered entrepreneurs until last September. This adversary status has had an evocative influence on the industry, creating to mistrust for new entrepreneurs to probe the business that divested. The franchise entrepreneurs are seen as fearing to take risks to start a business. The deceleration in the franchise industry players may be distantly linked to the situation of economic downturn.

\subsection{Sustainable Development: Franchise Organization}

This study is focusing on franchise survival to overcome the limitations when conducting business. Studies on sustainability in franchising are exiguous. (Sebastiania et al., 2014) studied corporate sustainability in franchising as an effective strategy. They considered in three major sights of sustainability such as economic sustainability, environmental sustainability, and social sustainability. Globally, a few franchise businesses especially for local franchisor, couldn't sustain over 10 years in the industry. The major reason is due to lack of cash business capital. After 10 years, only 16 percent of existing start-ups are still in business. With franchises, it's 90 percent (Fagan, 2017).Over the next 12 years, a new universal agenda of Sustainable Development 2030 (United Nations, 2015) towards sustainable economic growth plans will be applied to all countries in the world. The 2030 Agenda invites appropriate organizations including civil society, private sector to participate and contribute in this plan. As to form this goal on success, the approach are based on these core elements of social inclusion, economic growth and environmental ammunition as to fulfill the global essential such as education, health, financial stability and job opportunities.

Many surveys probed on how companies are addressing sustainability through generating greater opportunities, reducing inequalities, promoting integrated and sustainable management of the organization itself. Further study mentioned that many different uses of the term as well as its derivatives, such as social sustainability, environmental sustainability, sustainable development, sustainable living, sustainable future and others have emerged (Kopnin \& Blewitt, 2014).The different types of franchise business will require different strategies for sustainability. From previous survey, the stakeholders started to manage issues related to business sustainability, such as through the sustainability programs that they can make a positive contribution to their companies' for short and long-term value. These are referred to managing the company organization, financial, partnership relationship, behavior, capability, culture influences, policy enforcement and any other risks and opportunities which impacts to company profit as it is an important factor to the successful in business. The entrepreneurs have a role to play in improving the environment and dealing with business challenges. In order to be successful in such an approach, the organization structure need to balance and joint solutions for the limitations. The stakeholders should also take into account their product's life cycle costs and designing a good business environment for a sustainable business.

By gaining a deeper understanding of business trends may help the stakeholders make decisions that could aid in the sustainability of their business beyond 10 years of operation. Sustainability is when a business can continue in consecutive years of operation without closing the business (Landlearn NSW, 2010). As a partnership business, both franchisor and franchisee need to focus on managing sustainability to improve the organization, supply chain processes, pursue growth, and add value to their companies.Despite the fully explored of franchising roles it derive to the economic growth and they realized that sustainable are the most important principles towards successful business. According to a recent McKinsey (Worldwide management consulting firm) survey, 
entrepreneurs are doing so by pursuing goals that go far beyond earlier concern for reputation management, such as cost saving, developing employee's product knowledge, retaining and motivating employees, all of which help companies capture value through growth and return on capital.

\subsection{The Barrett Model}

Aligned with the sustainable strategy, Richard Barrett (1998) has developed the Seven Level of Sustainability theories, and clarified that the sustainable business environment need more participating from the stakeholders of companies. Barrett (2006) mentioned that improved consciousness of this challenge will help to change the world for the better. He suggested that all members from workers to stakeholders in the organization should align their values in the sustainable system. This model mentioned about how sustainability in the organization related to the sustainable in business.

According to many studies, a positive correlation exists between organization performance and sustainable in economic growth. If the franchise organization is constitutionally unsustainable, the company will require a major improvement to be as business model. Franchise entrepreneurs who leading the way in sustainable business practices is taking advantage of sustainable revenue opportunities. Moving forward, strategic actions need to be taken as ways of prevention barriers through enhancement in tacit and explicit knowledge to the franchise entrepreneurs and franchisor concerned as franchise consultants to keep improving the performance of franchise entrepreneurs. In order to determine a good image of relationship between both franchisor and franchisee in franchise business, it is important to overcome the problem through understanding the important of trust and transparency in business practice as it is an influential factor that needs to be sought and set forth in the context of business relationship. A study done by Grace, Gauzente and Weaven defined that ideally, both parties should gain value and develop a long term relationship (Grace \& Weaven, 2011) and in the case of franchisees, they are more concerned about the relationship and management of the system. This is including the important of sustainable in procurement management system as it will impact on the franchise business cycle environment. Dada et al. (2012) identify a number of possible support structures which can be used to maximize positive organizational outcomes from entrepreneurial activities.

The sustainable management system will integrates strategically to the business environment. By implementing sustainable business practices may affect the firm's profits. The challenges might make the franchise entrepreneurs capability cringe. But through a deeper understanding of business trend it may helps the franchise entrepreneurs could aid in the sustainability of the business beyond 10 years of operation. Sustainability is when a business can continue in consecutive years of operation without closing the business (Landlearn NSW, 2010). The sustainable balance scorecard (SBS) is one of the strategies that can help to measure the financial performance for short and long term measurement. Through this system, franchise entrepreneurs can forecast the alternative decision making on their business. Additional research is needed to identify the existing sustainability strategies of franchise business to determine if different strategies are required to sustain a business beyond 10 years (Miles, 2013).

\subsection{Strategic Direction Practices in Franchising}

A strategic direction is the most important forces in an organization strategy through exploring the firm direction from its proposition and chains. It is established the internal and external structure of the organization to achieve the company's goal and objectives. The strategic tactics will contribute to the vision achievement. Alon, Madanoglu, and Shoham (2017) said strategic agility explanation for managing franchising expansion during economic cycles. Despite, franchise entrepreneurs can respond to changes in the business environment so that they can improve and remain control to maintain progress towards the organizational values.

\subsubsection{Core Capability}

A decent capability including of the entrepreneurs skills and experience in franchising organization can lead firm success through different ways in different types of franchises. Alvarez and Basinets (2001) argued that entrepreneurial opportunities emerged when certain individual have insights into the value of these resources that others do not. Capability can be outlook as an intimate asset that concede firm to gain competitive advantage in the market place. The research literature on the effect of core competencies and capabilities in providing competitive advantage in start-ups is generally focused on high-tech ventures, especially those new firms with venture capital investment (Arthurs \& Busenitz, 2006; Baum \& Silverman, 2004; Zheng, Liu \& George; 2010). By understanding the barriers, weaknesses and strengths of the organization the capable entrepreneurs can enhance and expedite making adaption in a better ways. This will enable them to add value in competitive advantage for overall business development. According to Organizational Capability (OC) view, organizational capabilities influence the generating potential of a firm's governance structure (Ekeledo and Sivakumar 2004; 
Helfat et al., 2007; Madhok, 1997; Zhao et al., 2014). Furthermore, the OC perspective is rooted in the resource-based view of the firm (Barney, 1991; Pisano, 2015; Wernerfelt, 1984), which explains how firms gain competitive advantage by creating, deploying and redeploying resources and capabilities in a dynamic business environment (Arend, 2014; Rumel, 1984; Teece et al., 1997; Teece, 2014).

Previous studies show that entrepreneurs' capabilities influence the sustainable development in franchise organization. When a firm and its system can be managed systematically, the franchise organization will be perceived value and eventual success. More specifically, refer to the firm's capabilities of covering the whole range of value-chain activities (Porter 1985), such as procurement, production, marketing, human resources management, distribution, coordination, control and innovation capabilities, which are embedded within the firm's employees, routines and organizational process (Parmigiani \& Howard-Grenville, 2011; Teece, 2012; Sreckovic, 2017).

\section{H1: Core capabilities will have a significance influence on sustainable development in franchise organization}

\subsubsection{Government Support}

Government support or assistance plays a very important role towards the successful of franchise business. The different forms of assistance such as fund resources, knowledge, education, training, and policy practice can enhance the quality of the entrepreneurs in franchise business. The government's strategies for global targets should be incorporated in national strategic planning. This is executed through slobbering and guiding federal, state and local policymakers, monitoring legislative and constant activity impacting the franchise industry, conducting grassroots campaigns, participating in national and local coalitions, and promoting positive relations between franchisors, franchisees, and government officials and employees. New union organizing rules, changing overtime regulations, and proposed minimum wage increases all threaten to increase costs, reduce efficiency, and eliminate jobs at franchise small businesses across the country.

Besides, the ongoing processes are very important to recognize the relevant of sustainable development to the business environment. In USA, Small Business Administration (SBA) guaranteed lenders to qualified franchise borrowers. This financial support has created new direct and indirect jobs. International Franchise Association (IFA) supports maintaining current funding levels for the SBA and loan programs and encourages regulators to continue to ensure access to these loan programs for qualified small businesses. In Malaysia, franchise sector receives strong government support through PNS a specific agency and designed to spur the development of franchising by providing infrastructure facilities, financial assistance, advisory services, market access and other support programmes with the aim of developing capable and resilient Malaysian franchise to be competitive in the global market. In the 2015 budget, The Malaysian government has allocated about RM20 million to support franchise industry through Franchise Programme Initiatives (FPI).Currently, Malaysia has around 80 micro franchise businesses locally and is expecting around 40 franchises to exit abroad on a yearly basis (Lin, June 13, 2015).

The government interference in corrupt political systems also will lead to the weakness of law protection which affects the franchise business performance. Mentioned by Doherty and Alexander (2004), honesty and respect for the law, international franchisors will use equity modes of entry in countries with high corruption and weak legal protection (Alon, 2006). The government should protect franchise entrepreneurs against policies that could negatively impact the franchising community.

H2: Government Support will have a significance influence on sustainable development in franchise organization 


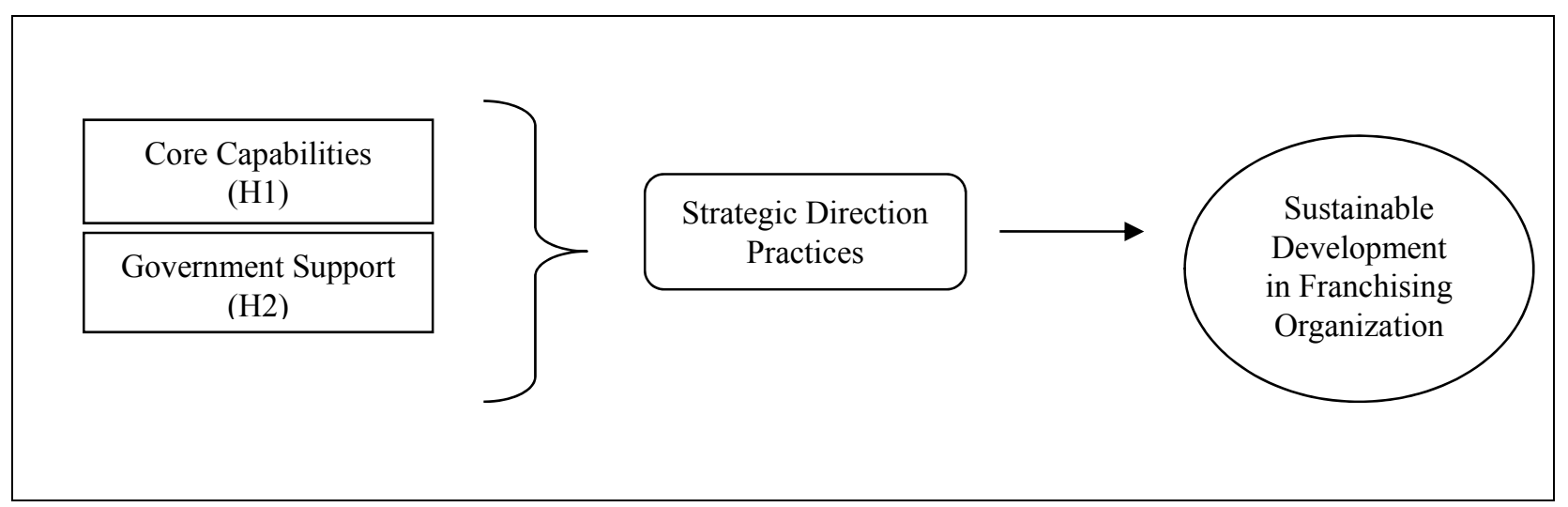

Figure 1. Proposed conceptual model

The above figure illustrates the relationship of indirect variables of Core Capabilities (H1) and Government Support (H2) towards direct variable of sustainable development in franchise organization.

\section{Discussion and Conclusion}

The purpose of this study is to conceptualize the strategic direction practices that purposely will impact into sustainable development in franchising. Agency theory is a dominant paradigm to explain franchising, as it's suggests that an agency relationship exists between a franchisor (the principal) and the franchisee (the agent). This theory has been used to argue many aspects that are based on two or more actors, such as a business model franchise (Shane, 1998), separation of ownership and control (Letza et al., 2004), mergers and acquisitions, opportunistic behaviour between managers and subordinates (El- Akremi et al., 2010; Mellewight et al., 2011) or an associated enterprise (Michael \& Combs, 2008; Salar \& Salar, 2014). Another such an important theory is RBV theory which has identified opportunities in terms of a unique resource for competitive advantage (Grewal et al., 2011).From a managerial perspective this study enhances a better understanding on current approach towards sustainable development in franchising. Franchise entrepreneurs should follow the process and give a maximize commitment on this approach in order to get a high quality outcomes for franchise organization to sustain.

Even though the conceptual theoretical benefaction of this research is multifarious, the foremost barriers of this study distortion in that the proposed affinities have not been exposed to empirical analysis. Nevertheless the main objective of this study is to extant a conceptual model of sustainable development in franchising. This study has certain limitations that offer opportunities for future research. This limitation could be resolved by exploring and expanding the model and adding variables that capture the effect of economic, society and the environment not only on local franchise organizations.

A sustainable creative value plans is very important for franchise entrepreneurs to prevent failure in organizations and ensure their survival. By developing a new proposed model through related dimensions and underpinning theories will predicts franchise entrepreneurs success or failure for economic sustainability. As expected core capability, government support and other related dimensions affect the stability of franchise organization. The initial years after a business start up are crucial to the organization's survival. Franchise business concepts are developed over time which adapted to business environmental changes. The franchise control mechanisms are important for the economic sustainability of the franchise.

The model of economic sustainability predicts that franchise entrepreneurs must prioritize on the stability of organization management and profits gaining in order to survive. Instead, the franchisor should focus on improving their organization by monitoring the limitations and keep finding the best method on how to overcome the barriers. We propose the studies should continue to develop the concept of sustainable development in relation to global franchising. By developing strong, efficient organization management and remaining consistent will develop consumer confidence in the brand. Besides, the establishment of consistent business processes are thoroughly innovating and adapting to consumers' concerns, and improve the brand with minimal disruption.Therefore, supporting and participation of stakeholders, entrepreneurs, academicians, researchers, and governments, future analysis can develop and expose a sustainable model of franchising. 


\section{References}

Adusumilli, S., Bhatt, D., Wang, H., Bhattacharya, P., \& Devabhaktuni, V. (2013). A low-cost INS/GPS integration methodology based on random forest regression. Expert Systems with Applications, 40(11), 4653-4659. https://doi.org/10.1016/j.eswa.2013.02.002

Agrawal, D., \& Lal, R. (1995). Contractual arrangements in franchising: An empirical investigation. Journal of Marketing Research, 213-221. https://doi.org/10.2307/3152049

Azoulay, P., \& Shane, S. (2001). Entrepreneurs, contracts, and the failure of young firms. Management Science, 47(3), 337-358. https://doi.org/10.1287/mnsc.47.3.337.9771

Bansal, P. (2005). Evolving sustainably: A longitudinal study of corporate sustainable development. Strategic management journal, 26(3), 197-218. https://doi.org/10.1002/smj.441

Bergen, M., Dutta, S., \& Walker Jr, O. C. (1992). Agency relationships in marketing: A review of the implications and applications of agency and related theories. The Journal of Marketing, 1-24. https://doi.org/10.2307/1252293

Blut, M., Backhaus, C., Heussler, T., Woisetschläger, D. M., Evanschitzky, H., \& Ahlert, D. (2011). What to expect after the honeymoon: Testing a lifecycle theory of franchise relationships. Journal of Retailing, 87(3), 306-319. https://doi.org/10.1016/j.jretai.2010.06.003

Booth, A., Gerding, E., \& Mcgroarty, F. (2014). Automated trading with performance weighted random forests and seasonality. Expert Systems with Applications, 41(8), 3651-3661. https://doi.org/10.1016/j.eswa.2013.12.009

Bordonaba-Juste, V., Lucia-Palacios, L., \& Polo-Redondo, Y. (2011). An analysis of franchisor failure risk: evidence from Spain. Journal of Business \& Industrial Marketing, 26(6), 407-420. https://doi.org/10.1108/08858621111156403

Brüderl, J., Preisendörfer, P., \& Ziegler, R. (1992). Survival chances of newly founded business organizations. American sociological review, 227-242. https://doi.org/10.2307/2096207

Calderoni, L., Ferrara, M., Franco, A., \& Maio, D. (2015). Indoor localization in a hospital environment using random forest classifiers. Expert Systems with Applications, 42(1), 125-134. https://doi.org/10.1016/j.eswa.2014.07.042

Chouinard, Y., Ellison, J., \& Ridgeway, R. (2011). The sustainable economy. Harvard Business Review, 89(10), $52-62$.

Closs, D. J., Speier, C., \& Meacham, N. (2011). Sustainability to support end-to-end value chains: the role of supply chain management. Journal of the Academy of Marketing Science, 39(1), 101-116. https://doi.org/10.1007/s11747-010-0207-4

Combs, J. G., Ketchen Jr, D. J., Shook, C. L., \& Short, J. C. (2011). Antecedents and consequences of franchising: Past accomplishments and future challenges. Journal of Management, 37(1), 99-126. https://doi.org/10.1177/0149206310386963

Crittenden, V. L., Crittenden, W. F., Ferrell, L. K., Ferrell, O. C., \& Pinney, C. C. (2011). Market-oriented sustainability: a conceptual framework and propositions. Journal of the Academy of Marketing Science, 39(1), 71-85. https://doi.org/10.1007/s11747-010-0217-2

Czarnecki, W. M., \& Tabor, J. (2014). Two ellipsoid support vector machines. Expert Systems with Applications, 41(18), 8211-8224. https://doi.org/10.1016/j.eswa.2014.07.015

Dobbs, M. E., Boggs, D. J., Grünhagen, M., Palacios, L. L., \& Flight, R. L. (2014). Time will tell: interaction effects of franchising percentages and age on franchisor mortality rates. International Entrepreneurship and Management Journal, 10(3), 607-621. https://doi.org/10.1007/s11365-012-0245-0

Franchise Economy. (2017). Retrieved July 27, 2017, from http://www.franchise.org/new-economic-impact-studyshows-franchise-businesses-produce-significant-impa ct-on-us-economy

Frazer, L. (2001). Causes of disruption to franchise operations. Journal of Business Research, 54(3), 227-234. https://doi.org/10.1016/S0148-2963(00)00118-1

Frazer, L., \& Winzar, H. (2005). Exits and expectations: why disappointed franchisees leave. Journal of Business Research, 58(11), 1534-1542. https://doi.org/10.1016/j.jbusres.2004.08.001 
Gaskill, L. R., Van Auken, H. E., \& Manning, R. A. (1993). A factor analytic study of the perceived causes of small business failure. Journal of small business management, 31(4), 18.

Gladwin, T. N., Kennelly, J. J., \& Krause, T. S. (1995). Shifting paradigms for sustainable development: Implications for management theory and research. Academy of management Review, 20(4), 874-907. https://doi.org/10.5465/amr.1995.9512280024

Gómez, R. S., González, I. S., \& Suárez, L. V. (2011). Service quality control mechanisms in franchise networks. The Service Industries Journal, 31(5), 713-723. https://doi.org/10.1080/02642060902833338

Grünhagen, M., \& Dorsch, M. J. (2003). Does the franchisor provide value to franchisees? Past, current, and future value assessments of two franchisee types. Journal of Small Business Management, 41(4), 366-384. https://doi.org/10.1111/1540-627X.00088

Harmon, T. R., \& Griffiths, M. A. (2008). Franchisee perceived relationship value. Journal of Business \& Industrial Marketing, 23(4), 256-263. https://doi.org/10.1108/08858620810865834

Horta, I. M., \& Camanho, A. S. (2013). Company failure prediction in the construction industry. Expert Systems with Applications, 40(16), 6253-6257. https://doi.org/10.1016/j.eswa.2013.05.045

ITA. (2016). Franchise Top Market Report.

Kalnins, A. (2005). Overestimation and venture survival: An empirical analysis of development commitments in international master franchising ventures. Journal of Economics \& Management Strategy, 14(4), 933-953. https://doi.org/10.1111/j.1530-9134.2005.00088.x

Kopnina, H. (2014). Sustainable Business: Key Issues.

Kosová, R., \& Lafontaine, F. (2010). Survival and growth in retail and service industries: Evidence from franchised chains. The Journal of Industrial Economics, 58(3), 542-578. https://doi.org/10.1111/j.1467-6451.2010.00431.x

Kurtulmuş, F., \& Kavdir, I. (2014). Detecting corn tassels using computer vision and support vector machines. Expert Systems with Applications, 41(16), 7390-7397. https://doi.org/10.1016/j.eswa.2014.06.013

Lafontaine, F., \& Shaw, K. L. (1998). Franchising growth and franchisor entry and exit in the US market: myth and reality. Journal of Business Venturing, 13(2), 95-112. https://doi.org/10.1016/S0883-9026(97)00065-7

López - Bayón, S., \& López - Fernández, B. (2016). Partner empowerment and relationship failure in franchising. Journal of Small Business Management, 54(4), 1059-1079. https://doi.org/10.1111/jsbm.12234

Michael, S. C. (1999). The elasticity of franchising. Small Business Economics, 12(4), 313-320. https://doi.org/10.1023/A:1008019418231

Olotu, O. A., \& Awoseila, F. (2011). Reinventing business growth through franchising in developing economies: A study of the Nigerian fast food sector. International Journal of Marketing Studies, 3(1), 162-170.

Paliwal, M., \& Kumar, U. A. (2009). Neural networks and statistical techniques: A review of applications. Expert systems with applications, 36(1), 2-17. https://doi.org/10.1016/j.eswa.2007.10.005

Park, T., \& Casella, G. (2008). The bayesian lasso. Journal of the American Statistical Association, 103(482), 681-686. https://doi.org/10.1198/016214508000000337

Phan, P. H., Butler, J. E., \& Lee, S. H. (1994). Learning: Key to leveraging the value of a franchise. Journal of Enterprising Culture, 1(3/4), 367-382. https://doi.org/10.1142/S0218495894000057

Romero-Martínez, A. M., Ortiz-de-Urbina-Criado, M., \& Ribeiro Soriano, D. (2010). Evaluating European Union support for innovation in Spanish small and medium enterprises. The Service Industries Journal, 30(5), 671-683. https://doi.org/10.1080/02642060802253868

Sánchez-Lasheras, F., de Andrés, J., Lorca, P., \& de Cos Juez, F. J. (2012). A hybrid device for the solution of sampling bias problems in the forecasting of firms' bankruptcy. Expert Systems with Applications, 39(8), 7512-7523. https://doi.org/10.1016/j.eswa.2012.01.135

Sebastiani, R., Corsaro, D., Montagnini, F., \& Caruana, A. (2014). Corporate sustainability in action. The Service Industries Journal, 34(7), 584-603. https://doi.org/10.1080/02642069.2014.886191

Shane, S. (2001). Organizational incentives and organizational mortality. Organization Science, 12(2), 136-160. 51. https://doi.org/10.1287/orsc.12.2.136.10108

Sivakumar, A., \& Schoormans, J. P. (2011). Franchisee selection for social franchising success. Journal of 
Nonprofit \& Public Sector Marketing, 23(3), 213-225. https://doi.org/10.1080/10495142.2011.586860

Soriano, D. R. (2005). The new role of the corporate and functional strategies in the tourism sector: Spanish small and medium-sized hotels. The Service Industries Journal, 25(4), 601-613. https://doi.org/10.1080/02642060500092469

Spinelli, S., \& Birley, S. (1996). Toward a theory of conflict in the franchise system. Journal of Business Venturing, 11(5), 329-342. https://doi.org/10.1016/0883-9026(96)00049-3

Spinelli, S., \& Birley, S. (1998). An empirical evaluation of conflict in the franchise system. British Journal of Management, 9(4), 301-325. https://doi.org/10.1111/1467-8551.00101

Tian, S., Yu, Y., \& Guo, H. (2015). Variable selection and corporate bankruptcy forecasts. Journal of Banking \& Finance, 52, 89-100. https://doi.org/10.1016/j.jbankfin.2014.12.003

Tsai, C. F., Hsu, Y. F., \& Yen, D. C. (2014). A comparative study of classifier ensembles for bankruptcy prediction. Applied Soft Computing, 24, 977-984. https://doi.org/10.1016/j.asoc.2014.08.047

Vázquez, L. (2009). How passive ownership restrictions affect the rate of franchisee failure. The Service Industries Journal, 29(6), 847-859. https://doi.org/10.1080/02642060902749419

Watson, A., Dada, O. L., Grünhagen, M., \& Wollan, M. L. (2016). When do franchisors select entrepreneurial franchisees? An organizational identity perspective. Journal of Business Research, 69(12), 5934-5945 https://doi.org/10.1016/j.jbusres.2016.05.006

Windsperger, J. (2002). The structure of ownership rights in franchising: an incomplete contracting view. European Journal of Law and Economics, 13(2), 129-142. https://doi.org/10.1023/A:1013676619490

Windsperger, J., \& Dant, R. P. (2006). Contractibility and ownership redirection in franchising: A property rights view. Journal of Retailing, 82(3), 259-272. https://doi.org/10.1016/j.jretai.2006.06.001

Wu, C. H., Tzeng, G. H., Goo, Y. J., \& Fang, W. C. (2007). A real-valued genetic algorithm to optimize the parameters of support vector machine for predicting bankruptcy. Expert systems with applications, 32(2), 397-408. https://doi.org/10.1016/j.eswa.2005.12.008

\section{Copyrights}

Copyright for this article is retained by the author(s), with first publication rights granted to the journal.

This is an open-access article distributed under the terms and conditions of the Creative Commons Attribution license (http://creativecommons.org/licenses/by/4.0/). 